\title{
Mapping the Promised Land
}

The Bible contains competing maps of Israel's homeland. According to the most common one, the Jordan marks Israel's eastern border. The region on the other side of this river may be home to some Israelite communities, but their territories are not properly part of the Promised Land. Competing with this map is another one that expands Israel's borders to embrace the Transjordanian territories. Texts that adopt this cartography assert that the monumental wars of conquest, fought during the days of Moses and Joshua, commenced prior to the crossing of the Jordan. These rival maps bear directly on questions of belonging and status for communities that affiliated with Israel, and in this first chapter of Part II we compare the conceptions of the conquest that inform these maps.

\section{THE JORDAN AS THE NATION'S BORDER}

The reader of Numbers and Deuteronomy cannot help but notice how the narrative, structured as the itinerary of Israel's odyssey from Egypt to Canaan, has one penultimate destination in sight and toward which it ineluctably advances - namely, "the plains of Moab across the Jordan from Jericho" (Num. 22:I). ${ }^{\mathrm{I}}$ This location is the final camping place for the Israelites, from which they send out spies to reconnoiter Jericho, cross the Jordan, and eventually take possession of the Promised Land (Josh. 2:I, 3:I). It is also where Moses, in Deuteronomy, delivers his valedictory address to Israel. ${ }^{2}$

\footnotetext{
${ }^{\mathrm{I}}$ See also 26:3, 26:63, 33:48-50, 35:I, 36:I3. $\quad{ }^{2}$ See Deut. I:5, 29:I, 32:49, 34:I.
} 
The line demarcating the Pentateuch from the Former Prophets (Joshua-Kings) is drawn precisely at this point in the narrative, where the nation crosses the Jordan and commences the conquest. By severing the first five books from those that follow, the Pentateuchal laws and promises can continue to have validity long after the loss of the territorial sovereignty that Israel secured during the days of Moses and Joshua. The Pentateuch sets forth the command to conquer the land, as well as the criteria for maintaining possession of it. Following it, the Former Prophets tell how it was conquered but then later, because of the nation's wrongdoing, forfeited to foreign control. In this canonical structure, the Prophets witness to the abiding veracity of the Torah. ${ }^{3}$

The division of Pentateuch and Prophets may be compared to the way this literature maps territory. Just as the Jordan marks the canonical boundary between the Torah and the Nevi'im, it also constitutes the territorial border to what is referred to as "Canaan" (Num. 32:32; Josh. 22:9, I0) or "the territory that Yhwh has given the Israelites" (Num. 32:7). Likewise, the texts often draw a distinction between the inhabitants of the Transjordan and those of the Cisjordan; only the latter are consistently designated "Israelites." 4

The book of Numbers identifies the Promised Land in two different ways. A host of texts include the Transjordan within Israel's borders. While the Israelites do not initially plan to occupy this country and ask for permission to travel through it, as we saw in Part I, they end up conquering it after its rulers, Sihon and Og, deny them passage (Num. 2I; see also Num. 32). The block of material related to the seer Balaam and his subverted curses (Num. 22-24) presupposes Israel's presence in lands east of the Jordan.

In contrast to this view, most other texts in Numbers confine the wars of conquest to Canaan. When Moses sends out the first group of spies to reconnoiter the land, they go up from the south toward Hebron and northwards; nothing is said about the Transjordan (Num. I3:2I-24). Later in the book, after the death of the exodus generation, Moses delineates the nation's borders (34:I-I2), and when he does, he defines the

${ }^{3}$ In keeping with this Torah/Nevi'im (Pentateuch/Prophets) division, the final lines of the former declare that "never has there arisen a prophet in Israel like Moses" (Deut. 34:IO-I2). Likewise, Malachi 3:22, the conclusion of the Nevi'im, reminds the reader to heed the Torah of Moses.

${ }^{4}$ See, e.g., Num. 32:I7; Deut. 3:I8; Josh. 22:II-34 (yet notice how also Judg. 20-2I presents the "Israelites" over against the "Benjaminites"). 
eastern boundary as running along the Jordan from the eastern slopes of the Sea of Galilee (Kinneret) down to the Dead Sea:

[T]he boundary shall continue downward and abut on the eastern slopes of the Sea of Kinneret. The boundary shall then descend along the Jordan and terminate at the Dead Sea. That shall be your land as defined by its boundaries on all sides. Num. 34:I I-I 2

A brief caveat (34:13-15) that follows this passage addresses the situation in the Transjordan. Moses now asserts that his earlier directions apply only to nine and a half tribes, since two and a half tribes (Reuben, Gad, and the half tribe of Manasseh) had "already taken their inheritance beyond the Jordan at Jericho eastward, toward the sunrise." If the passage originally did not include this caveat, we could explain the way verse I 2 reads like a conclusion ("That shall be your land as defined by its boundaries on all sides"), while what follows feels like an afterthought and addendum. That the Jordan is Israel's eastern border is assumed also in Numbers 32, a text that we will consider in Chapter 4.

With few exceptions, the same view is adopted in Deuteronomy. Throughout the book, the Jordan looms large on the horizon. It's in anticipation of crossing this river that Moses delivers his protracted prebattle speeches and proclaims a prodigious new law code. Israel is warned that it will forfeit its right to remain in its homeland if it fails to heed the code, and this threat relates solely to the territories west of the Jordan:

I call heaven and earth to witness against you today: You shall certainly and quickly perish from the land that you are crossing the Jordan to possess; your days shall not be long on it, for you shall be utterly wiped out. Deut. 4:26

Yhwh's marching orders, with which the book begins, do not even mention the Transjordan when laying out an expansive description of the land that he promised to the nation's ancestors:

Yhwh our god spoke to us at Horeb [Sinai], saying: "Your residence at this mountain has been long enough. Turn and make your way to the hill country of the Amorites and to all their neighbors in the Arabah, the hill country, the Shephelah, the Negeb, the seacoast - the land of the Canaanites and the Lebanon, as far as the Great River, the Euphrates. See, I've placed the land before you. Go, take possession of this land that Yhwh swore to your ancestors - Abraham, Isaac, and Jacob - to give them and their seed after them." Deut. I:6-85

5 For the "hill country of the Amorites" as referring to the Cisjordan, see Num. I 3:29; Deut. I:I9, 27, 44. 
Moses later orders the nation, as soon as it crosses the Jordan (27:I-8), to write the Laws on plastered stones atop Mount Ebal (located in the heart of the West Bank at Nablus/Shechem).

In these texts, we cannot help but wonder about the tribes in the Transjordan. Are their territories not also part of Israel's homeland? Are the communities that take up residence there not equally members of the nation? While Moses keeps his gaze firmly fixed on the Jordan and the country that lies west of it, he does at least refer to Israel's wars on the eastern side of the river. The significance of these events, however, has little, if anything, to do with the territories themselves. Their enduring meaning is to be found instead in the lessons and motivation they provide for the nation as it prepares for the campaign that really matters - the one undertaken in Canaan, on the western side of the Jordan. ${ }^{6}$

\section{THE WADI ARNON IN DEUTERONOMY}

As our study will continue to demonstrate across a wide span of texts, biblical war commemoration is characterized by a plurality of competing perspectives. Thus, as Moses reflects on Israel's recent history in the second chapter of Deuteronomy, he diminishes the significance of the Jordan as a boundary. According to the view advocated in this passage from the book, the wars of conquest began not at the Jordan, but at a wadi in the Transjordan called the Arnon (today called Wadi el-Mojib). ${ }^{7}$

The book of Numbers presents the Israelites conquering and occupying the kingdom of Sihon in the area from the Arnon northwards to the Jabbok (the Zarqa River). ${ }^{8}$ Their reason for doing so is that Sihon had attacked them, as we saw in Part I. When Moses retells the story in Deuteronomy, he claims that after all the warriors of the exodus generation were dead, Yhwh delivered to him these marching orders:

${ }^{6}$ On the Bible's competing maps of Israel's homeland, see Nili Wazana, All the Boundaries of the Land: The Promised Land in Biblical Thought in Light of the Ancient Near East (Winona Lake: Eisenbrauns, 20I3).

7 The Wadi el-Mojib originates in the mountains of Gilead and winds through a deep ravine for some eighty miles before it falls into the eastern side of the Dead Sea in line with Engedi. On the historical role of the region in Israel's history, see Israel Finkelstein, Ido Koch, and Oded Lipschits, "The Biblical Gilead," Ugarit Forschungen, 43 (20I I), I3 I-I 59.

${ }^{8}$ The Zarqa has springs at 'Ain Ghazal (a site dating back to the Neolithic) and runs through deep ravines for some sixty-five miles before emptying into the Jordan. The Arnon and the Jabbok are two of the three main tributaries that enter the Jordan between the Sea of Galilee and the Dead Sea (the other being the Yarmouk River to the north). 
Up! Set out and cross the Wadi Arnon! See, I have delivered into your hand Sihon the Amorite, king of Heshbon, and his land. Begin and occupy! Provoke him to engage in battle! Deut. 2:24

Later in his address, Moses claims that Yhwh reissued the same orders:

And Yhwh said to me: See, I have begun to deliver Sihon and his land to you. Begin [and] occupy, so that you may take possession of his land! Deut. 2:3 I

Nowhere in Numbers are we told that Yhwh issued such a command. Moreover, Numbers 32, which we study in Chapter 4, recounts how two of Israel's twelve tribes petition Moses to settle in the very same region. Far from being a command from Yhwh, their desire to live there initially presents a major moral problem, and Moses harangues them at length for even contemplating it as an option. In the end, he accedes to the tribes' entreaty, yet the length and complexity of the text leave no doubt that its authors were troubled by the presence of an Israelite population in the Transjordan.

The natural borders demarcated by rivers and bodies of water frequently serve also as political borders. In ancient battle accounts, a military engagement officially commences when a belligerent crosses a waterway. (For armies from Mesopotamia, the crossing of the Euphrates conventionally marked the launch of a western campaign. ${ }^{9}$ ) Yet why were the scribes who reworked this first speech in Deuteronomy so deliberate in memorializing the nation's history in this way? They could have had Moses ignore the wars in the Transjordan or at least interpret them as a prelude to the conquest. By doing so, his address would have been more in harmony with what we have seen to be the dominant view in these texts. How then are we to explain the fact that the speech now shifts attention from the Jordan to the Arnon?

As a battle orator with a clear political agenda, the Moses of Deuteronomy is not unique. The naming of wars, and the status of battles in relation to these wars, are often highly contentious matters. ${ }^{\text {IO }}$ In our case, the reason why scribes shifted attention from the Jordan to the Wadi Arnon is, I suggest, twofold. First, in keeping with the rhetorical function already noted, the crossing of the Arnon anticipates the Jordan. This

9 See the examples collated in K. Lawson Younger, Jr., Ancient Conquest Accounts: A Study of Ancient Near Eastern and Biblical History Writing (Sheffield: Sheffield Academic Press, I990).

to See Ashplant and Dawson, Politics of War Memory; Walter Laqueur, "Memory and Naming in the Great War" in John R. Gillis (ed.), Commemorations: The Politics of National Identity (Princeton: Princeton University Press, I994), I 50-I67. 
speech, with its counterpart in the framing sections of Deuteronomy, is a kind of eve-of-battle address that aims to boost national morale. The recounting of past triumphs against two Transjordanian kings, Sihon and Og, serves as a demonstration of Yhwh's power in assisting Israel for the larger campaign in Canaan $(3: 2 \mathrm{I}) .{ }^{\mathrm{II}}$

Yet the success after crossing the Arnon does more than merely foreshadow the victories east of the Jordan. In addition to this rhetorical purpose, there's a second, polemical reason for the shift. The emphasis on the command "begin" (hāhēel rāš [lārešet 'et-'arṣô] in 2:24, 3 I) reflects a larger ideological concern that prompted scribes to revise history. By including the battles against Sihon and Og among the monumental wars of conquest, and by shifting the boundary from the Jordan to the Arnon, these parts of Moses's speech elevate the importance of the eastern territories and ascribe to them the status of the Promised Land.

The Transjordan is the setting for the final passage of Deuteronomy, and thus of the Torah. It is there that Moses, in his dying days, ascends Mount Nebo and surveys the land promised to the nation's patriarchs. Notably, the first region that Yhwh shows him is Gilead, a prominent eastern region:

Moses went up from the steppes of Moab to Mount Nebo, to the summit of Pisgah, opposite Jericho, and Yhwh showed him the whole land: Gilead as far as Dan; all Naphtali; the land of Ephraim and Manasseh; the whole land of Judah as far as the Western Sea; the Negeb; and the Plain - the Valley of Jericho, the city of palm trees - as far as Zoar. And Yhwh said to him, "This is the land of which I swore to Abraham, Isaac, and Jacob, 'I will give it to your offspring.' ...” Deut. 34:I-4

At this lookout point, Moses meets his death and is buried by Yhwh. A series of competing Pentateuchal texts present his death and burial outside the land as punishment for his sins in the events surrounding the first spy mission (Num. I4:20-25) or alternatively for his wrongdoing in striking the rock (Num. 20:I2). These explanations evolved with the Pentateuchal narrative and reflect its shifting emphases. The earliest texts simply locate Moses's death (at the consummate age of I 20 years), along with the place where the deity buries him, in the land of Moab, without identifying either as divine retribution (see Deut. 3 I:I-6). Indeed,

${ }^{I}$ As commentators often point out, the language in Deuteronomy 2:24-25 is very similar to Joshua 4:24 and 5:I, where it refers to the crossing of the Jordan. See the discussion in F. Langlamet, Gilgal et les récits de la traversée du Jourdain (Jos., III-IV) (Leuven: Peeters, I969), 72-76. 
the claim that Moses was buried - by Yhwh himself - in the Transjordan may represent an attempt to validate the presence of communities in the region that affiliated with Israel. ${ }^{\mathrm{I} 2}$

\section{THE TRANSJORDAN IN JOSHUA}

The book of Joshua, as a whole, severely undercuts the significance of the Transjordan, directing readers' attention from the eastern to the western bank. The narrative begins with Yhwh's directions to Joshua: "Moses, my servant, is dead. Now prepare to pass over this Jordan." Soon thereafter Joshua sends out spies to reconnoiter Canaan. Later the nation crosses the river, and the ceremonious entrance into Canaan is reported in great detail. Upon setting up camp, the Israelites construct a monument that connects the parting of the Jordan with that of the Red Sea. In this way, the authors build a literary bridge from one event to the other, dissociating all the events "in the wilderness" from those in the Promised Land.

Once the nation has crossed the river, the men perform rites of circumcision, an act described as the repudiation of the Egyptian reproach they had borne in their flesh up to this point. At this time, manna also ceases and the nation celebrates Passover. In keeping with Canaan's special status, the captain of Yhwh's (heavenly) armies appears to Joshua on the eve of battle after crossing the Jordan. Finally, after Israel's first victories, Joshua builds an altar on Mount Ebal and, in keeping with Moses's exhortation, inscribes the Laws on them. ${ }^{13}$

The book presents these and many other momentous events as happening in Canaan, not in the territories of the Transjordanian tribes. Their special character reinforces the Jordan as the border of the Promised Land. ${ }^{\mathrm{I}}$

${ }^{12}$ On both Sihon and the place of Moses's death, see Angela Roskop Erisman, "Transjordan in Deuteronomy: The Promised Land and the Formation of the Pentateuch," Journal of Biblical Literature, I32 (20I3), 769-789. Honorific burial by the king is depicted in a wide array of ancient Near Eastern texts. With Michael J. Chan, I discuss these texts and their significance for the interpretation of Deut. 34; see "An Honored Burial for a Faithful Servant" (paper presented at the Annual Meeting of the Society of Biblical Literature, San Francisco, November 20 I I, available on my Academia. edu web page).

${ }^{13}$ This narrative (perhaps originally consisting of just 8:30, $3 \mathrm{Ib}-33 \mathrm{a}, 34$ ) is likely older than Moses's commands in Deuteronomy 27:I-7.

${ }^{\mathrm{I} 4}$ For example, when military coalitions form against Israel, they consist solely of rulers from the Cisjordan (see esp. Josh. 9: I, as well as chaps. Io and I I). Joshua has the military chiefs place their feet on the necks of these kings as he declares: "Thus shall Yhwh do to all the enemies against whom you fight!" (I0:24-25). Such does not happen with the kings 
Like other biblical books, Joshua is neither neat nor simple. It contains a set of strategically placed texts that depart from the focus on Canaan and call attention to the tribes of Israel living beyond the Jordan:

I:I 2-I 8 - A reminder to Reuben, Gad, and the half tribe of Manasseh to cross over and fight for the other Israelites.

4:I $2-\mathrm{I} 3$ - A short notice that these two and a half tribes did cross over armed for battle.

I 2:I-7, I3:7-33, I 4:3-4 - References to the lands east of the Jordan that these tribes occupied.

22:I-34 - A complex account of the Transjordanian tribes being relieved of their military duty and returning to their wives and children.

24:8 - A brief reference to the settlement of the Transjordan by the nation as a whole.

This series of texts was likely added in the final stages of the book's composition. Most scholars today agree that the earliest editions of Joshua consisted solely of material from chapters I-I 2. Without the paragraph in $\mathrm{I}: \mathrm{I} 2-\mathrm{I} 5$, the notice in $4: \mathrm{I} 2-\mathrm{I} 3$, and the revision of chapter I 2 , these early editions of the book would have completely ignored the eastern territories. As for the second half of the book, the historical review in chapter 23 never refers to the eastern territories. To the contrary, it explicitly names the Jordan as the eastern border:

See, I have given to you, by your tribes, [the territory of] these nations that still remain, and that of all the nations that I have destroyed - from the Jordan to the Mediterranean in the west. Josh. 23:4

The following chapter contains a second address from Joshua, and this time the commander retells Israel's history of conquests by beginning with Israel's battles against the Amorites on the eastern side of the Jordan:

I brought you to the land of the Amorites who lived beyond the Jordan. They engaged in battle with you, but I delivered them into your hands. I annihilated them for you, and you took possession of their land. Josh. 24:8

Sihon and Og. Indeed, the book of Joshua constitutes a veritable "History of Cisjordanian Wars," and as such points up the nonexistence of a comparable "History of Transjordanian Wars." 
The two speeches thus present competing views of the nation's past. While the first ignores the territories east of the Jordan, the second is more expansive in its historical purview. ${ }^{\mathrm{I} 5}$

The core narratives of Joshua are circumscribed by two frames: an outer one relates to Torah observance for the nation as a whole ( $\mathrm{I}: \mathrm{I}-9$ and chaps. 23-24), while an inner one treats the issues posed by the eastern tribes and their allegiance to the Torah (I:IO-I 8 and 22:I-34). The book also consists of two equal parts: whereas in the first half all Israel comes together to fight as a united nation, in the second half they disband in order to take possession of their respective tribal territories. The sequence of assembling and dispersing is repeated in chapters $\mathbf{2 3 - 2 4}$, where the tribes come together one final time to declare the Torah to be their perpetual point of unity, before Joshua sends them back to their respective territories.

Thus, in its final form(s), the book still presents itself as a history of the invasion and occupation of Canaan (i.e., the territory west of the Jordan), yet it widens the pool of protagonists to include the Israelite tribes that reside in the Transjordan. What unites the latter with "all Israel" is affirmed at both ends of the narrative (I:I $2-\mathrm{I} 8$ and 22:I-6) - valorous service for their Cisjordanian kin ("brothers") and allegiance to the laws of Moses. The former is a "fraternity in arms," while the latter is loyalty to shared statutes, resembling what is called in German political theory Verfassungspatriotismus (lit. patriotism to the constitution). I will expand on these points in the coming chapters.

\section{CONTESTED TERRITORY}

Our survey thus far has focused on the Pentateuch and Joshua, yet, throughout the wider biblical corpus, many texts identify the Transjordan as not only an integral part of Israel's homeland but also as the site of crucial events in the nation's history - and in the lives of the patriarch Jacob, the judge Jephthah, and the prophet Elijah, to mention only the most obvious examples.

Competing maps, which exclude the Transjordan from that nation's sacred homeland, were widely embraced in the Second Temple period. ${ }^{\mathrm{I} 6}$

I5 This observation apart, a growing number of scholars agree that the two addresses in chapters 23-24 evolved from of an exhortation to fear Yhwh that did not include a review of the nation's past.

${ }^{16}$ A useful discussion of these texts is provided by Moshe Weinfeld, "The Extent of the Promised Land: The Status of the Transjordan" in G. Strecker (ed.), Das Land Israel in biblischer Zeit (Göttingen: Vandenhoeck \& Ruprecht, I983), 59-75. 
For example, Ezekiel's “Temple Vision" (chaps. 40-48) has expansive portions of the southern Levant as part of Israel's territory, but when it comes to the eastern border, it draws a line "between the Gilead and the land of Israel, with the Jordan as a boundary ... " (47:18). ${ }^{17}$ Similarly, the Nehemiah Memoir identifies the prominent Transjordanian leader Tobiah as one who possesses property in the temple at Jerusalem, has many allies (through connubium et commercium) in Judah, and bears a name that reflects reverence of Yhwh. Yet the Memoir also maligns this figure as a foreigner (an Ammonite) who opposes the restoration of "the children of Israel" (Neh. 2:IO). From the Hellenistic period, the book of I Maccabees portrays Gilead as a home to Jewish communities, even though it is not a hospitable place: after hearing of the Maccabees' triumphs, "the Gentiles of the Gilead" assault "the Israelites who lived in their territory" (I Macc. 5:9, emphasis added). In response, one of the brothers, Simon, undertakes a rescue operation and escorts these communities to Judah. ${ }^{18}$

Also, many of the rabbis denied the sacred status of the Transjordan. Thus, in a commentary on Deuteronomy, Rabbi Simeon excludes the Transjordan from the law of first fruits. The reason is that the law begins, "When you arrive in the land that Yhwh your god is giving you" (Deut. 26:I-2, emphasis added); in the narrative, Israel had yet to cross the Jordan. The Transjordan represents territory that "you conquered by yourself" (see Num. 2I:23-35), rather than received from Yhwh as a part of the promise made to the patriarchs (Sifre 299 and 30I). His scriptural argument thus draws directly on our texts. Despite a long history of Jews dwelling in the Transjordan, the modern state of Israel, for both political and religious reasons, ultimately did not lay claim to territories in this region.

Hitherto, our study has examined how biblical scribes engaged in war commemoration to address political issues posed by the nation's neighbors. The battle accounts in Numbers $2 \mathrm{I}$ trace Israel's territorial claims in the Transjordan to the time of Moses, and what prompted the composition of these accounts were, inter alia, disputes with neighboring polities that laid claim to the same territory. ${ }^{19}$ In keeping with the polemical-

${ }^{17}$ The case of Ezekiel is noteworthy since the book stands in close proximity to Priestly writings, which we examine in Chapter 4.

${ }^{18}$ The account of the Jews seeking refuge in a fortress and then sending messengers to the Cisjordan in search of help is similar to the account of Saul rescuing the refugees at Jabesh-Gilead in I Samuel II.

19 The taunt-song of Numbers $21: 27-30$ and the poetic oracles of Balaam in chapters 22-24 witness to such disputes with neighboring powers. The overlap between the taunt-song 
apologetic character of these passages, the enemies are consistently depicted as initiating military aggression, which in turn leads to Israelite occupation. ${ }^{20}$

In the remaining chapters of Part II, we explore a different use of war commemoration. Our investigation will show how biblical scribes made a case for the belonging of disputed members of the nation by constructing memories of their exceptional wartime service. While the accounts in Numbers 2I appeal to memories of foreign aggression to argue for the nation's longstanding territorial claim in the Transjordan, the texts that we are about to study construct war memories to advocate full-fledged membership for the communities that occupy the Transjordan.

Our objective is to discern the various ways these texts construct the bonds of filiation that hold together the communities from both sides of the Jordan. As we shall see, their authors sought to transcend territorial divisions by affirming that the nation is united not only by fraternity but also by fidelity to one deity, to the laws revealed by that deity to one prophet (Moses), and to worship of that deity in one place.

and Jeremiah 48 suggests a late composition; see Erasmus Gaß, Die Moabiter: Geschichte und Kultur eines ostjordanischen Volkes im I. Jahrtausend v. Chr. (Wiesbaden: Harrassowitz, 2009).

20 The same apologetic interest that prompted the composition of these texts also informs their use in depictions of later territorial disputes, as we see, for example, in the contest between Jephthah and the Ammonite king discussed in Chapter I. I treat the polemics against the Transjordan in David, King of Israel, chap. 5 . 